\title{
HON. JOEL JONES' OPINION IN THE CASE OF THE FISHERIES ANNEXIDD TO THE SHORES OF THE RIVER DELAWARE. ${ }^{1}$
}

It must be assumed-the question having been settled by judicinl authority-that neither the Charter of Charles II., granting to the Duke of York the province of New Jersey, nor that of the same king granting the province of Pennsylvania to William Penn, conveyed to either, any portion of the soil of the bed of the river Delaware, below the low water mark; and consequently that the right to it remained in the crown during the colonial condition of those provinces. At the Revolution, and by force of that event, all the rights of the crown in that river were devested, and the adjacent boundaries of those States, by the law of nations, were, thereupon, extended, so as to meet in the middle of the river. ${ }^{2}$

In 1783 , the jurisdiction of the river was definitively settled by compact or treaty between the two States, and the islands therein were distributed between them substantially in conformity with that law. This compact, according to its terms, was to remain forever irrevocable by either party, without the concurrence of the other. ${ }^{3}$

In forming this compact, the States acted as independent sovereignties, untrammeled by any higher compact or law. They had indeed become parties to the Articles of Confederation, which were finally ratified and agreed to on the 1st day of March, 1781; and this instrument made provision, in the ninth article thereof, for the settlement of differences between two or more States concerning their respective boundaries and jurisdictions; but it contained nothing which impaired the right of the States to adjust their boundaries by compact or treaty, in such manner as they thought proper. It will be borne in mind, also, that the Federal Constitution was not then formed. The state of Pennsylvania became party to that instrument on the 12th of December, 1789, and the State of New Jer-

'We are indebted to the courtesy of Judge Jones for permission to publish this interesting and important opinion.-Eds. Am. Law Reg.

${ }^{2} 4$ Wash. C. C. Rep. 285.6; 1 Bald. 72 , 73 ; 5 Wheat. Rep. 379.

s $2 \mathrm{Sm}$. Laws of Pa., 78,79 . 
sey on the 18th of the same month. The compact, therefore, at the time it was formed, violated neither of those instruments. ${ }^{1}$

A question, howerer, may be raised, whether these States did not, by becoming partics to the Federal Constitution, mutually surrender to the control of the national government, some of the matters previously settled by the compact; and therefore, whether they did not thereby, to some extent, mutually revoke the same. It is in this way only (it is conceived) the binding effect of the compact can be abridged or impaired, or any question raised touching the constitutionality of any of its provisions.

A comparison of the tro instruments will show that, with the exception of the right of navigation of the river secured by the first article of the compact to the citizens of the contracting States, the several matters contained therein do not come within the sphere of the Federal Constitution.

The second article establishes merely a concurrent jurisdiction between the contracting States, with certain specified exceptions, within and upon the water botween the shores; and the third article distributes between them the islinds, islets, and dry lands within the bed and between the shores of the river. It provides also for the case of any new island, which might thereafter be formed within the river. These arrangements have been practically adhered to by the States ever since the ratification of the compact, and are in fact the only existing law upon the subject. ${ }^{2}$

The first article declares the river, in the whole length and breadth thereof, between the said States, a common highway, equally free and open for the use, benefit and adrantage of the contracting parties. This provision, so far as it is applicable to the river within the tides, was superseded (it may be granted) by that clause of the Federal Constitution which vests in the Congress of the United States the power to regulate commerce with foreign nations and among the several States. It may be conceded also, that so much of the proviso annexed to this clause, as relates to the interruption of the fisheries by vessels, belongs to a subject generally within the

$14 \mathrm{Sm}$. Laws, Appendix, pp. 431, 434.

2 See Act of Pa. 23 Feb. 1810, Scc. 3, Pamph. Jaws, 15-16. 
power of Congress. Yet as the power reserved by the States is, by express words, limited to the regulating and guarding of the fisherics annexed to their respectire shores, against unneessary interruption during the season for catching shad, by vessels riding at anchor on the fishing ground, it cannot, by any fair construction, be considered as surrendered by the said States. But this question is not involved in the present inquiry.

The only remaining clause is that which reserves to each of the legislatures of the said States the power of regulating and guarding the fisheries annexed to their respective shores, against interruption by persons fishing under claim of a common right, on said river. That the States had this power, previously to the compact, in virtue of their sovereignty, is proved by the best writers on the law of nations, and by the practice of civilized States. "It is vain to object," says Grotius, "that by the law of nature or of nations, it is allowable for all to take wild beasts, fish, and birds. He who has the sovereignty may forbid the capture of such animals, and thus prevent the acquisition of property therein by their capture. Strangers even, are obliged to obey such a law, as well as those born in the country. It is not true that the law of nature or of nations permits their capture by all, except upon the supposition that the civil law of the particular State does not forbid it, and when it does so, even the law of nature requires that the rule of the civil law should be observed."'

The Constitution of Pennsylvania, adopted on the 28th September, 1776, contains a regulation upon this subject. which, though superseded by the Constitutions of 1700 and 1838 , proves the power of a sovereign State to dispose of and regulate at pleasure, things which are common by the law of nature. But it is enough to say, that the affirmative of this question is assumed by the compact itself. New Jersey and Pennsylvania have recognized in their sovereign capacities the existence of private rights of fishery within the tide waters of the Delaware river, in opposition to all persons claiming a common right of fishing therein. Each of the said States has

1 See 5 Mass. 266, 269; 2 Conn. 481; 20N. Y. Rep. 90; 1 Halst. 78; Gro. Bk. II. Ch. ii. \& V. See Vattel, Bk. 1, Ch. Xx. $z z 230,239$. 
bound itself irrevocably to this provision of the compact as firmly as to any.other contained therein. There is no clause in the federal Constitution which expressly or by implication requires, that the fisheries in the navigable waters of the United States shall be common to all persons; nor any which impairs the power of the States to enact laws to regulate, guard or control the fisheries within their boundaries in such manner as they shall see proper. This clause, therefore, as well as the second and third clauses of the compact, remains in full force, incapable of being affected or altered by any Constitution of either State adopted subsequently to the ratifcation of the compact, but only by some other compact or treaty, or concurring act of both the contracting States. ${ }^{1}$

The compact thus recognizing the existence of private rights of fishery at that time, it will elucidate the question to inquire briefly into their origin.

By the law of England, every navigable river within the realm, so far as the sea ebbs and flows, is deemed a royal river; and the fisheries therein, as belonging to the crown by prerogative; yet capable of being granted to a subject, to be held or disposed of as private property. It has indeed been denied that a prerogative grant of a royal fishery for private purposes, is or has been valid in England since Magna Charta, but the contrary has been settled by a series of decisions from the earliest times; and the patents granted by Charles II. to the Duke of York and William Penn, before mentioned, are instances of the exercise of that porrer. It is true, that the profit of such fisheries, when retained by the crown, was not commonly taken and appropriated by the king, unless they were of extraordinary value. ${ }^{2}$

But were this a doubtful question, there can be no doubt that by the Revolution, the States of New Jersey and Pennsylvania acquired the sovereignty of the Delaware river, discharged of any such restriction. It was doubtless in their power, at the origin of their independent governments, to declare the river common to all persons, for the purposes of fishing, as well as of a highway. It was' equall 5 within their power to appropriate the fisheries to the public

15 Sm. Laws, App. p. 430,

2 Plowd. 154 a; Davies' Rep. 155; 7 Co. Rep. 16 a. 
use, as so many prerogative rights devested by the Revolution from the crown. They had also the power to validate and establish on the basis of law, the precarious or qualified rights which had grown up during the colonial condition; and this course was the one actually adopted by both the States, as the only one compatible with public policy and private justice. This will appear by the following considerations.

Although no part of the river beyond low-water mark was conveyed by Charles II. either to the Duke of York or to William Penn, yet the people of the two colonies and the provincial legislatures dealt with the river, in many respects, as though all of the rights of the crown were included in and conveyed by the patents. Thus, by an Act passed 13 George, A. D. 1726, the legislature of Pennsylvania claimed by virtue of the letters patent to William Penn, that the river Delaware, as well as all other great streams and rivers of the province, had become and ought to be and continue as common streets and highways, for the free and undisturbed use of all such as might have occasion to pass and repass in and over the same. By another and eariier act, (4 Anne. A. D. 1705,) the legislature of Pennsylvania gave authority to the sheriffs and coroners of Philadelphia to act as water bailiffs, and to execute and perform all things pertaining to that office, upon the Delaware river, \&c., \&c.; thus, in fict, extending the authority of those officers from shore to shore of that river, although no part of it, as has been shown, beyond low water mark, was actually within the bailiwick of the sheriffs, or even within the Province. ${ }^{1}$

Again, in 1761 the Tegislature of Pennsylvania passed an act for the preservation of fish in the river Delaware, in which the Legislature of New Jersey soon after concurred, by a similar act. This law, it was observed by the court, in the case of Hart vs. Hill, was predicated of the idea of separate fisheries existing in that river; in other words, of fisheries belonging to citizens of one or the other colony. This observation was, in fact, extended by the court, to all the laws regulating fisheries in the Delaware, as well

'Laws of Pa., ed. 1728, p. 342; Lans of Pa. ed. 1742, p. 106-7. 1 Sm. Laws p. 231. 
as to the compact between Pennsylvania and New Jersey before cited. $^{1}$

Such then, being the practical construction of the patents previous to the Revolution, without interference by the crown of England, whaterer might have been the result, had the matter been contested by the king during the colonial condition, they were at least assertions of claim, to which the Revolution gave validity in the form and to the extent they had been recognized by the common law of the provinces or the general usages of the people,-by the courts and by the Provincial Legislatures. Hence the origin of separate or private fisheries in the navigable parts of the river Delaware.

In this way also, we may account for a fact noticed by Huston $J$., in the case just cited, so far as it respects the river Delarrare; that "although we have no act of Assembly (in Pennsylvania) expressly creating the right (of fishery, ) yet we have acts regulating, and in some respects restraining it, of an early date." In respect to the king they were, in strictness of law, infringements of his prerogative rights, although in respect to all other persons, they were universally considered the property of the owner of the shore to which they were annexed, until separated from it by act of liw or some lawful conveyance. ${ }^{2}$

There was indeed no motive, on the part of the crown, to interfere with this view of the subject; as the provinces were too remote, and the fisheries not of a nature to admit of any considcrable revenue. Within the tide waters-where we find the earliest and most valuable fisheries - they could not be established without great labor and expense: It is well known, that shad and herring passing up navigable streams, like the Delaware, keep within or along the channcl or deep parts of the stream, and not along the shores or above the low water mark. The channel is in fact the fishery. It was necessiry therefore, to clear the channel (which was from twelve to thirty or forty feet deep) of rocks, logs and other obstructions, sometimes to the extent of half a mile in breadth, and even more in

i See Laws of Pa., ed. 17/5 p. 424-5; 1 Whart. 136.

2 I Whart. 131; Daries' Rep. 154. 5; 1 Whart. 138; 1 Bald. 76. 
length. Incidentally, this was a benefit to the navigation, to a considerable extent. Besides, it was necessary to prepare nets thirty feet in width or depth and of sufficient length to sweep through this large space; also to erect cabins on the shores and to employ, during the season of fishing, a considerable number of experienced hands to carry on the business. ${ }^{x}$

It was greatly to the advantage of the public, that fisheries should be established and maintained. The owners of the shores, undertook this labor and expense. No other person indeed had the right to enter upon appropriated lands for that purpose. There was in fact no reason why the crown should not permit them to do so, for their own profit and the general advantage of the colonists, under such regulations as the provincial authorities saw proper to adopt.

By sufferance then, rather than by express authority or grant of the crown, private rights of fishery originally grew up and have exister in the navigable waters of the Delaware river, from the origin of the colonies. At the Revolution, all prerogative rights were extinguished, and the common law of the colonies became, by universal consent, the common law of the States. The case of Hart vs. Hill, before referred to, shows that the people and the Courts of Pennsylvania recognized a private right of fishery in that river in 1745 and 1752 ; and in the case of Bennet vs. Boggs the court said "it is admitted, that from a very early period of the history of the state (of New Jersey,) shore fisheries (along the Delaware river) have been considered as private property, capable of bcing devised and alienated with or separated from the land, to which they were annexed, subject to taxation and taxed as other real estate. It is not pretended, that there ever existed a common right of fishing in the citizens of the State on or over the lands thus owned to low water mark. ${ }^{2}$

So valuable had these rights become in 1784 , and so often had they been transmitted, as property, from hand to hand, by descent,

I See Irart vs. IHill, I Whart. 137; Aet 15 April, 1851. Sec. 9. P. I. $714 ; 4$ Griff. Law Register 1290.

21 Whart. 136; 1 Bald. 70. 
partition and conveyance, that neither State would consent, as has been shown, to surrender to the other, its power of regulating and guarding those annexed to its own shore and claimed by its citizens. It was a power, neither State could surrender without exposing itself to the just claims of its citizens for indemnity against the injury that might result therefrom, inasmuch as the right of property has no foundation or security but the law; and every State is, at least morally bound to protect against invasion, that which has been taken and held as property, on the faith of its own institutions; and this obligation was in no respect impaired by the Revolution: The communities remained the same and the obligations of each to observe good faith towards all its loyal members and maintain the rights they had acquired as colonists, were not only not dimininished, but on the contrary increased, by the acquisition of the sovereignty.

It is proper to add, that the compact containing this reservation, was in effect a solemn repudiation of the pretensions of those, who, at that time, made claim of a common right of fishing. The power reserved by each State, in the terms employed, is several and ample for the protection of the owners of the fisheries annexed to its own shores, without aid from the other contracting State; although it has uniformly been exercised by concurrent Acts of Legislature of which, the Acts of Pennsylvania of the 30th $\mathrm{MIarch}, 1781$ - the 7th April, 1786-the 8th of February, 1801-the act of the 23d of February, 1809-the act of New Jersey of the 26th November, 1808, appended to and adopted by the last mentioned act-the act of New Jersey of 20th of Nov. 1809, concurred in by an act of Pennsylvania of the 19th Narch, 1810-the act of New Jersey of 28th Nov., 1822, concurred in by the act of Pennsylvania of the 20th January, 1823, and the act of $\mathrm{New}$ Jersey passed in 1833, concurred in by an act of Pennsylvania passed 3d April, 1837, are examples. ${ }^{1}$

Besides, the State of Pennsylvania has shown the intention to appropriate to public use the value of the fisheries connected with

14 Sm. L. 118, 123; Pamph. Laws 1808, pp. 14, 15; 5 Sm. Laws, 117, P. I. 1837 , p. 198. 
any unappropriated island in the Delaware belonging to that State. This appears by an act passed January 27 th, 1806 , directing the sale of unappropriated islands in such parts of the river Delaware, \&c., as are by law declared public highways. The second section of this act requires the appointment of persons to estimate and value the land in any such, island, in doing which, they are required to have " regard to the soil, wood, fisheries and other advantages, and local situation thereof." So far as sales have been made under this act, of islands in the river Delaware, having fisheries annexed thereto, the state of Pennsylvania is bound by contract to maintain the title to the fisheries which may have been thus granted, as appurtenant to such islands, on the ground of the consideration paid for them. It is not in this point of view however, that this act is cited, but merely to show a prerogative claim of that commonwealth, to fisheries connected with unappropriated islands in that river, inconsistent with the claim of a common right of fishing; and the purpose on her part, to dispose of such fisheries, as property, for the benefit of the public treasury. ${ }^{1}$

In passing this act, it will be observed, the Legislature made no distinetion between islands situated along the shore of the river, and those in or near the middle of it, or having a channel on both sides. Whether any such islands have been disposed of under this act; or even, whether any such remained to be disposed of, at the time the act was passed, it is not important to inquire. It is suffcient to say, that the words of the act are inconsistent with the claim of a common right of fishing along or near any of the islands described therein. They indicate also very clearly, that in the opinion of the legislature, no such claim. could lawfully be made in any part of the river, inasmuch as a common right of fishing, if it exist at all, must exist in every part of the river, and may be exercised, as well on fishing ground connected with the islands, as on that connected with the shores.

Upon the whole, then, I am of the opinion, that the fisheries established in the river Delaware, previously to the Revolution or since, by the owners of the shores opposite thereto, and hitherto

24 Sm. Laws, 268. 